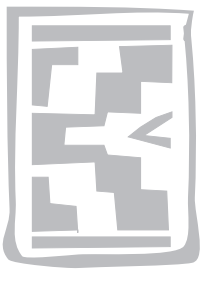

\title{
Review of blackfly (Diptera: Simuliidae) control in South Africa
}

\author{
E. MYBURGH ${ }^{1}$ and E.M. NEVILL ${ }^{2}$
}

\begin{abstract}
MYBURGH, E. \& NEVILL, E.M. 2003. Review of blackfly (Diptera: Simuliidae) control in South Africa. Onderstepoort Journal of Veterinary Research, 70:307-317

The medical, veterinary and economic importance of blackflies in South Africa, and the historical development of blackfly control programmes in various South African rivers, are reviewed in this paper. In 1996 it was estimated that blackflies can cause more than R 88 million damages per annum along the middle and lower Orange River where Simulium chutteri is considered the main pest species. A clear link between the construction of dams and the spread of the blackfly problem was shown. Four phases characterize the development of blackfly control in South Africa: (1) during the 1960s blackflies in the Vaal River were controlled with DDT; (2), during the 1970s and into the 1980s blackflies were controlled using water-flow manipulation; (3) when used at strategic times, water-flow manipulation could be used to enhance the effect of natural predator populations; and (4) during the 1990s the organophosphate temephos and toxins produced by the bacterium Bacillus thuringiensis var. israelensis were tested for their efficacy against blackflies. The larvicides temephos and $B$. thuringiensis proved to be effective and are still used in several control programmes. The latest research focuses on the factors that influence adult blackfly survival and annoyance, as well as the development of methods that can be used to protect sheep from blackfly attacks.
\end{abstract}

Keywords: Bacillus thuringiensis var. israelensis, blackfly, economic importance, Orange River, Simulium, temephos, water manipulation

\section{INTRODUCTION}

Blackflies were not considered significant pests in South Africa but developed pest status along many rivers following the building of dams, canals, irrigation schemes or hydro-electrical plants along those rivers (Nevill 1988). This is because impoundments promote the development of suspended organic

1 ARC-Onderstepoort Veterinary Institute, Blackfly Field Station, Upington, South Africa. Present address: P.O. Box 835, Duiwelskloof, 0835 South Africa. E-mail: myburg@lantic.net

2 ARC Onderstepoort Veterinary Institute, Private Bag X5, Onderstepoort, 0110 South Africa

Accepted for publication 12 June 2003-Editor material and a more constant seasonal flow of water, which in turn creates ideal conditions for immature blackflies (Howell \& Holmes 1969; Car 1983; Nevill 1988 ) to increase in numbers in rapids downstream of such structures (Chutter 1963; Palmer 1991). Moreover, these structures change many of the rivers from seasonal to perennial and thus create ideal and continuous breeding conditions for simuliids (Myburgh 1999a; b).

At present, blackflies are common and significant pests along the Orange, Vaal, Great Fish, Sundays and Gamtoos Rivers. Periodic outbreaks are also experienced along the Eerste, Olifants and Berg Rivers (Edwardes \& Palmer 1994; Palmer 1997) (Fig. 1). It is expected that blackflies may acquire pest status along the Liebenbergsvlei River follow- 


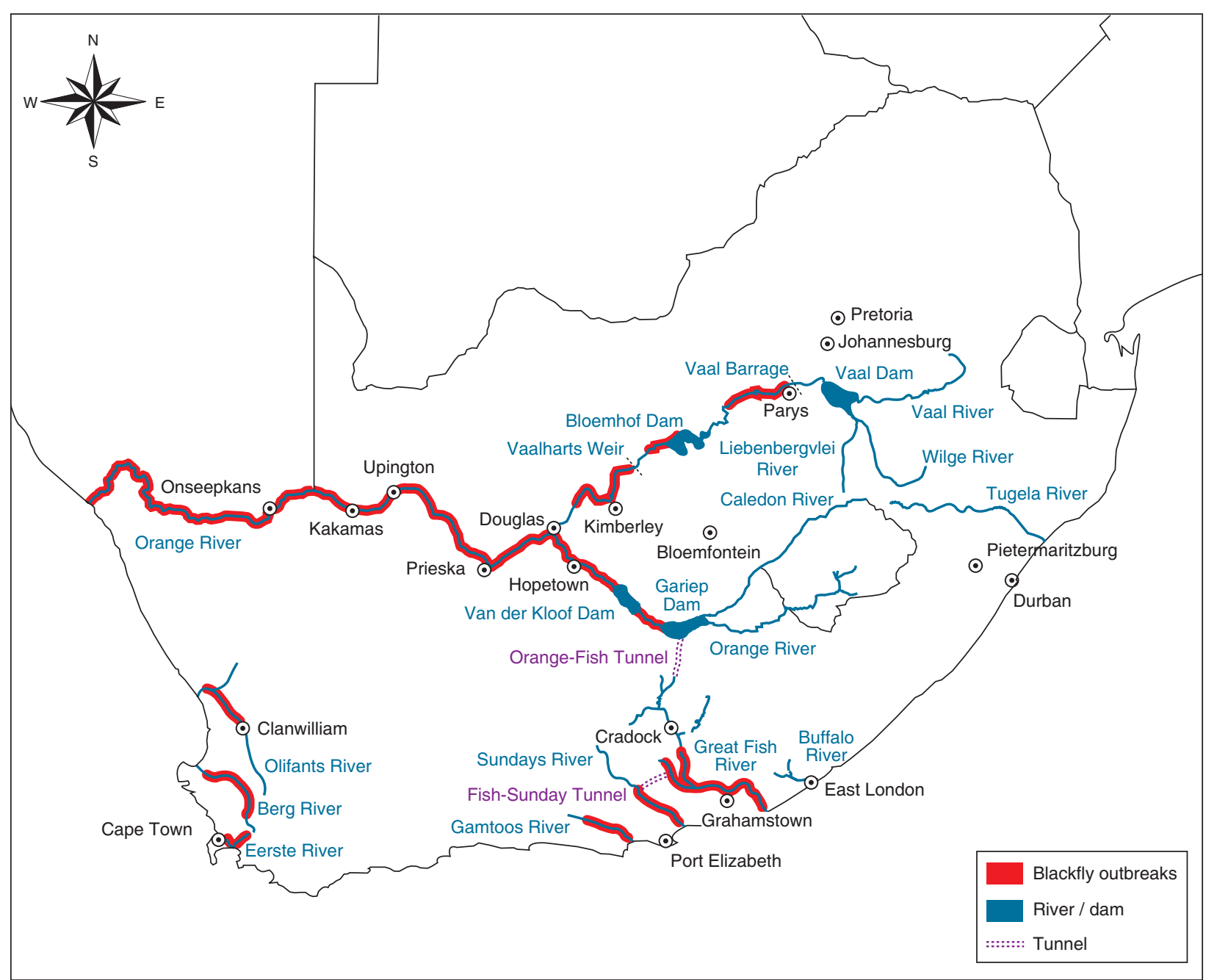

FIG. 1 Known blackfly problem areas in South Africa

ing the completion of the Lesotho Highlands Water Scheme, although so far this has not happened (Fig. 1). Currently 39 blackfly species are known to occur in southern Africa (Palmer 1997; Palmer \& De Moor 1998). These include five members of the genus Paracnephia and 34 Simulium species (Palmer 1997). The latter genus includes the mammalian pests Simulium chutteri and Simulium damnosum sensu latu and the avian pest species Simulium adersi and Simulium nigritarse sensu latu.

The ARC-Onderstepoort Veterinary Institute (ARC$\mathrm{OVI}$ ) has been involved in the development and implementation of blackfly control programmes for more than three decades. In this paper, the advances made towards the control of blackflies in South Africa are reviewed, the medical, veterinary and economic importance of the pest is outlined and current and future blackfly research by the ARC-OVI is discussed.

\section{Medical, veterinary and economic importance of blackflies}

In addition to feeding on sugar, which is used as a fuel for flight (Hocking 1953; Davies, Peterson \& Wood 1962; Hunter 1977; Sutcliffe 1986), anautogenous adult female blackflies also require a blood meal (Welton, Bass, Ladle \& Merritt 1987; Palmer 1997; Gibson \& Torr 1999) for ovarian development (Davies \& Peterson 1956; Peterson 1959; Crosskey 1990). Because of their blood-feeding activity they are considered ideal disease vectors (Crosskey 1990) and are probably best known for transmitting the filarial nematode Onchocerca volvulus to humans (Nelson 1991; Davies 1994; Hougard, Yaméogo, Sékétéli, Boatin \& Dadzie 1997; Gibson \& Torr 1999). The resulting disease known as onchocercosis or "river blindness" has left more than 20 million people infected and millions blind in West Africa and South America (Rodriquez-Perez, 
Reyes-Villanueva \& Rodriquez 1995; Samba 1995; Hougard et al. 1997; Molyneux \& Davies, 1997). Furthermore, in humans, the bites of some blackfly species can cause allergic reactions known as "blackfly fever" or simuliotoxicosis (Crosskey 1990; Palmer 1997). This condition is characterized by swelling, itching, haemorrhage and oedema (De Villiers 1987) which, in severe cases, requires medical attention (Mason \& Schemanschuk 1990).

In animals, blackflies have been implicated in the spread of leucocytozoonosis (Anderson \& Voskuil 1963; Crosskey 1993), bovine onchocercosis, (Crosskey 1990; Hadi \& Takaoka 1995), the cytoplasmic polyhedrosis virus, the iridescent virus, vesicular stomatitis virus (Bernardo \& Cupp 1986; Bridges, McCluskey, Salman, Hurd \& Dick 1997; Maré 1998), avian trypanosomes (Crosskey 1993), myxomatosis (Williams \& Williams 1966; Kettle 1984) and Dirofilaria species (Simmons, Edman \& Bennett 1989). It has also been shown that allergic reactions to blackfly bites, similar to that described in humans, can lead to the death of cattle (Mason \& Schemanschuk 1990). In South Africa, simuliids have been implicated in the spread of two pathogens to animals namely a Chlamydophila (previously Chlamydia) sp., that causes blindness in sheep and abortion in cattle (De Moor 1982a), and Rift Valley Fever virus. Mechanical transmission of this virus, by $S$. chutteri, may have contributed to the major Rift Valley Fever outbreak between Prieska and Groblershoop in 1975 (Mclntosh, Jupp, Dos Santos \& Barnard 1980).

Blackflies readily attack exposed parts of the bodies of livestock, such as the eyes, ears and teats (Anderson \& Voskuil 1963), and the resulting wounds are prone to secondary infections which sometimes lead to the death of animals (Palmer 1997). Blackflies also cause considerable irritation (annoyance) to livestock (Anderson \& Voskuil 1963; Crosskey 1990; Kok, Fourie \& Oberem 1994). In South Africa, sheep under attack from blackflies will bundle together and hide their heads underneath each other. During these periods the sheep do not feed or mate, and this results in loss of mass and a reduction in lambing percentage (Palmer 1997). In southern New Zealand and Canada the irritation value alone of the pest is high enough to have it classified as the most significant insect pest in these areas (Gibson \& Torr 1999). According to Edman \& Simmons (1985) the annoyance of haematophagous Simulium species can be severe enough to warrant large-scale control operations. Blackfly annoyance also leads to economic losses through reduced efficiency of agricultural and industrial workers, interference in recreation, and reduced real estate values (Mason \& Shemanschuk 1990).

Although there are numerous reports of blackfly epidemics in South Africa, only Steenkamp (1972) has made a detailed study of the economic impact of the pest. He reported physical destruction of the teats of some cows and a reduction in milk production of up to $35 \mathrm{~kg}$ milk per week per cow (30-50\% reduction). In poultry he found a $10-15 \%$ reduction in egg production. Other reports confirm that cows can loose their udders and sheep their ears as a result of secondary infections that develop because of blackfly wounds (De Moor 1986). During a more recent, though smaller-scale survey along the Vaal River, farmers reported that blackflies killed lambs, caused losses of $60 \%$ in total farm stock production and reduced milk production by as much as $55 \mathrm{I}$ per cow per week (O’Keeffe 1985). In 1996 the Northern Cape Agricultural Union estimated that blackflies, if left uncontrolled, can cause potential losses of more than R88 million per annum to the stock industry along the Orange River (Palmer 1997). This figure is based on a $25 \%$ reduction in lamb production and excludes other figures such as land depreciation and tax losses to the State.

Today $S$. chutteri is considered to be the most important blackfly pest species in South Africa. This species occurs along the Orange, Vaal and Great Fish Rivers, and, to a lesser extent, the Sundays River, but it is most abundant and causes the largest economic problems along the middle and lower Orange River (Palmer 1997). Simulium chutteri is a large-river species endemic to southern Africa which, under favourable conditions, can become the most abundant blackfly species in this region with larval densities exceeding 500 000/m² (Palmer \& De Moor 1998). It is a multivoltine species with 11-13 generations per annum (Palmer, Edwardes \& Nevill 1996). Simulium chutteri occurs throughout the year although an increase in biting activity is usually experienced in spring and early summer (August to November) and autumn (April to May) (Jordaan \& Van Ark 1990; Palmer, Edwardes \& Nevill 1995b) suggesting that it is adapted to moderate weather conditions.

\section{History of blackfly control in South Africa}

Attempts to control blackflies in South Africa started with the use of DDT in 1965. This was followed by water manipulation in the 1970s and 1980s, strategically timed to maximize the effect of inver- 
tebrate predators. Since the late 1980s the use of larvicides has been tested and developed into planned control programmes. These phases are described in more detail below:

\section{Phase 1: DDT applications}

Periodic blackfly outbreaks, especially following floods, were experienced along the Vaal River prior to 1940 (Howell \& Holmes 1969), but after the completion of the Vaal Barrage in 1923, Vaalharts Diversion Weir in 1936 and Vaal Dam in 1938, blackfly numbers steadily increased (De Moor 1986). Since 1950 frequent blackfly outbreaks have been reported along the Vaal River (Howell \& Holmes 1969; Nevill 1988). Four species have been incriminated in the outbreaks: S. chutteri (Chutter 1968; Howell \& Holmes 1969), S. damnosum s.l., S. nigritarse (Steenkamp 1972) and S. adersi (Begemann 1980). After a severe blackfly outbreak during 1963 in the Warrenton District (Chutter 1968; Howell \& Holmes 1969) the first extensive studies were undertaken on the ecological requirements of local blackfly species (Chutter 1968). These were followed in 1965 by the first attempts to control the pest using DDT which, at that time was described as "the perfect weapon for the perfect target" (Brown 1962).

Between 1965 and 1967 DDT was applied several times to the Vaal River from structures suspended above sluice gates or by fixed-wing aircraft (Howell \& Holmes 1969). The DDT applications resulted in the growth of benthic algae on rocks, which was attributed to the eradication of most invertebrates as a result of the low target specificity of DDT (Car \& De Moor 1984). Nevill (1988) noted that the algal mats had the benefit that they did not allow new generations of blackfly larvae to attach to affected rocks. Although high larval mortalities were obtained with DDT, rapid reinfestation was recorded following the disappearance of the algal mats (Howell \& Holmes 1969). The control programme was suspended in 1967 because of the environmental damage caused by DDT. After major floods in 1974, Begemann (1980) found blackfly larvae in great numbers in the Vaal River, indicating that the blackfly problem had not been solved.

\section{Phase 2: Water-flow manipulation}

The 1970s saw the spread of the blackfly problem along the Vaal River after the completion of the Bloemhof Dam in 1970 (Car 1983). Moreover, during the period 1972 to 1978 the Gariep and Van der Kloof Dams were completed in the Orange River and this allowed $S$. chutteri to also develop to pest proportions in this river system (Nevill 1988; Jordaan \& Van Ark 1990). In 1975 the Orange Fish Tunnel, linking the Gariep Dam to the Great Fish River (Fig. 1 ), was completed and reports indicated that $S$. chutteri also developed pest status in the Great Fish River during the years following the completion of the tunnel (Coetzee 1982; O'Keeffe 1985).

These problems led to the second phase in the battle against blackflies, namely the use of water-flow manipulation. Water-flow manipulation is the process by which the water levels of rivers are artificially fluctuated to expose and desiccate the sessile blackfly pupae as well as forcing the larvae to move to undesirable sites where they are prone to starvation and predation (Howell, Begemann, Muir \& Louw 1981). Howell et al. (1981) started flowfluctuation trials in 1977 at the Vaalhartz Diversion Weir and found a drop in the numbers of immature blackflies for up to $30 \mathrm{~km}$ downstream of the weir. They followed this with trials in the Orange River during 1978 at the Van der Kloof Dam where water flow was interrupted for approximately $66 \mathrm{~h}$. Here they reported similar successes. The authors recommended that cut-offs in water-flow be implemented twice annually, during May and August. They furthermore claimed that $S$. chutteri lost its pest status in sections of the river where regular water-flow fluctuations were implemented. Separate trials by Car (1983) confirmed that a reduction in the water level of the Orange River reduced the number of immature blackflies in the river. The greatest effect on larvae could be found during winter and he recommended a cut-off in water-flow during July/August when the majority of the population is in the larval stage.

\section{Phase 3: Integrated water flow manipulation}

During the same period De Moor (1982a; b), working along the Vaal River, proposed a third method of blackfly control. This method involved an integrated approach where data on the life-cycle, population dynamics and microhabitat preferences of the six most abundant Simulium species, and their natural aquatic invertebrate predators, were used to determine the best time to carry out a series of river-flow cessations. Water-flow regulation was then applied to halt the build-up of populations and maintain S. chutteri at levels at which they could be controlled by natural predators. Although integrated water-flow manipulation can be regarded as the most cost-efficient and ecologically least disruptive of the available methods, De Moor \& Car (1986) 
noted that the method is limited by the availability of impoundments upstream of Simulium breeding sites and is therefore impractical.

Furthermore, from the start of the 1980s there were major agricultural developments along the Orange River and the traditional crops were expanded to include winter crops such as wheat and peas. Nevill (1988) concluded that the need for additional irrigation water, as well as the release of water from the Gariep and Van der Kloof dams, for the generation of hydroelectricity, made the further use of strategically-timed water-flow manipulation impractical along the Orange River. Researchers also realized that the long distances over which water flow had to be manipulated made the sustainable use of this method unrealistic (Jordaan \& Van Ark 1990). Waterflow manipulation was therefore discarded as a control method along the Orange River.

\section{Phase 4: Bti and temephos applications}

$B t i$ is an acronym for Bacillus thuringiensis Berliner var. israelensis de Barjac (serotype $\mathrm{H}-14$ ) a naturally occurring bacterium that, on sporulation, produces protein crystals with larvicidal activity against filterfeeding Diptera such as mosquitoes and blackflies. The protein crystals are classified as a delta-endotoxin and must first be activated by the digestive proteases of the target organism to become a toxic substance. Once ingested the alkaline conditions of the stomach dissolve the crystal and release the delta-endotoxin. The toxin has an affinity for the stomach wall lining causing the cells to first swell then rupture. When enough stomach cells burst, the alkaline fluid of the midgut can enter the blood. This increases the alkalinity of the blood and results in a general paralysis and death. Blackfly larvae need to filter out sufficient spores for Bti to be effective. This larvicide therefore works best in clear water where there is no dilution of spores by silt particles or algae. Also because Bti is a biological product produced by a fermentation process, whereafter it must be formulated for use in water, it has so far been impossible to produce a very highly concentrated product.

During the 1980s Bti gained ground as a biological agent for the control of simuliids after studies by Undeen, Takaoka \& Hansen (1981) and Lacey, Escaffre, Philippon, Sékétéli \& Guillet (1982) indicated that this blackfly larvicide was effective in other parts of the world. Following these reports, Car \& De Moor (1984) conducted trials during 1982 in the Vaal River and reported high larval blackfly mortal- ities. Laboratory and field trials by Car (1984) also showed that Bti was effective in controlling blackflies, but that its toxicity was considerably reduced in polluted rivers with a high sewage level and high chloride concentration. Subsequent trials in the Orange River during 1983 confirmed the efficacy of $B t i$ against blackflies and its low toxicity to non-target organisms (De Moor \& Car 1986).

The alternative to Bti was the organophosphate temephos ["Abate"-SA Cyanamid (Pty) Ltd], specially formulated for blackfly control as a $20 \%$ suspension concentrate. This larvicide had proven to be very effective and environmentally acceptable in West African rivers during the onchocercosis control programme. Temephos can and is best used in rivers that have silt particles in suspension. The larvicide adsorbs to the silt particles that, in turn, are filtered out and concentrated in the midgut of the blackfly larvae, causing them to poison themselves. Due to its mode of action and the low dosage rate used, less temephos formulation is needed to produce the same effect as Bti. Also temephos can be applied to silt-laden rivers, which is often the case at high flow rates.

Large-scale trials to control blackflies breeding in the Orange River, using Bti and temephos larvicides, started in 1991 after a severe blackfly outbreak followed a flood in 1988 (Palmer 1997). Fortunately, new, improved and more practical Bti formulations ["Teknar HP-D" (Registered trademark of Thermo Trilogy Corporation registered and marketed in South Africa by Wefco Marketing) and "Vectobac" (Valent BioSciences (Pty) Ltd)] had become available. Both Bti and temephos proved to be effective against S. chutteri larvae (Palmer 1995) and led to the establishment of an annual blackfly control programme along the Orange River (Palmer, Edwardes \& Nevill 1996). However, since each of the two larvicides has a different mode of action and different formulations, the river conditions under which they can be used also differ. The application of presently available formulations of $B t i$ is restricted to rivers with relatively low flow rates less than 100 cubic metres per second (< 100 cumecs). Application is usually by helicopter, the Bti being sprayed $50 \mathrm{~m}$ to $100 \mathrm{~m}$ above rapids, in a zig-zag path across the river to allow dispersion before the Bti reaches the larvae attached to rocks in the rapids. In this way the larvae have a greater chance of filtering out a lethal dose of Bti spores. Temephos is the only larvicide which can be applied to the Orange River when flow rates are 300 cumecs and higher. Under these circumstances it is effective for up to $50 \mathrm{~km}$ 
downstream of the point of application. At such high flow rates it is applied from a vehicle moving slowly across a bridge or from a boat (Palmer, Edwardes \& Nevill 1995a, b; 1996).

Various studies on the impact of these two larvicides on non-target organisms showed that they were safe for use in the Orange River (Palmer 1993; Palmer \& Palmer 1995). At the same time trials were done to assess the downstream carry of these two larvicides (Palmer et al. 1995a) and on the timing of larvicide applications (Palmer et al. 1995b). Furthermore, methods were developed for rapidly assessing larval and pupal abundance before and after larvicide applications (Palmer 1994). These trials lead to the development of larvicidal programmes in the Vaal and Orange Rivers. However, due to financial and logistical constraints, the Vaal River larvicidal programme was discontinued.

Currently the National Department of Agriculture implements the Orange River Blackfly Control Programme (ORBCP). Between two and 19 temephos and Bti applications are needed annually to control the pest (Palmer 1997; Myburgh 1999b). Ideally the two larvicides should be used alternately to inhibit selection of resistant individuals, especially to temephos. However, in practice this is not always possible as at high flows, i.e. greater than $100 \mathrm{cu}$ mecs, Bti cannot be used due to the high dosage and costs involved. For a detailed review of the ORBCP see Palmer et al. (1996), Palmer (1997; 1998) and Myburgh (1999b).

\section{BLACKFLY CONTROL PROGRAMMES ALONG THE VAAL, GREAT FISH, SUNDAYS AND GAMTOOS RIVERS}

\section{Vaal River}

Simulium chutteri is the predominant species although $S$. damnosum can also be a problem. Following the discontinuation of larviciding sections of the Vaal River, weekly water-flow interruptions were introduced in 1997 at Bloemhof Dam and Vaalharts Weir. This approach was very successful (Myburgh, 1997; 1998a, b; 1999a). For various reasons it has been difficult to develop an effective routine water-flow interruption programme at the Vaal Barrage, but this may still be possible. A major shortcoming of this approach is that water-flow cannot be interrupted when dams are full. An integrated water-flow/larvicide programme is needed for the Vaal River.

\section{Great Fish River}

The main pest species is $S$. chutteri, although $S$. damnosum, Simulium medusaeforme, S. nigritarse and Simulium momahoni have also been recorded. Blackfly breeding is mainly restricted to 33 rapids over a distance of $90 \mathrm{~km}$. This river has a median flow of 3.5 to 4.6 cumecs. It is therefore feasible for local farmers, using hand-held sprayers, to apply larvicide across the entire width of the river. First control attempts started in 1984 using an early formulation of Bti, but were discontinued (Palmer 1997).

Following the success of the ORBCP, the latest formulation of Bti was used in a renewed Fish River control programme. This got underway in 1993. In order to overcome the negative effect that the high silt load in this river has on the effect of the larvicide, the Bti is now applied at double the recommended dosage rate. The larvicide is supplied by the National Department of Agriculture (Myburgh 1997; 1998a, b; 1999a).

\section{Sundays River}

The blackfly problem along the Sundays River also started when an additional and regular supply of water was received from the Orange River after 1977, via the Fish-Sundays Tunnel and canal (Palmer 1997). The main species are S. adersi (lower river) and $S$. damnosum (upper river), while S. chutteri numbers are low. This is a small river with a median flow of only 2-3 cumecs. The main breeding is restricted to 26 rapids over $41 \mathrm{~km}$, but in-stream vegetation creates additional breeding surfaces (Palmer 1997). It is therefore possible for persons, in the affected sections, to monitor and treat the river themselves, if trained and supplied with Bti. Initial control efforts were made in 1995 by Sunlands Irrigation Board. In late 1997, Sundays River Citrus Cooperative took over the responsibility, the Bti being supplied by the National Department of Agriculture (Myburgh 1997; 1998a, b; 1999a).

\section{Gamtoos River}

This is a small river with a median flow varying between 1.5 and 2.0 cumecs. No S. chutteri occur here, the main species being $S$. adersi and $S$. medusaeforme (Palmer 1997). In 1995 the river was surveyed from the air for rapids which are the main breeding sites. Fifty-five rapids over a distance of $66 \mathrm{~km}$ were recorded but in-stream trailing vegetation increased the available surfaces for blackfly larvae to attach. Gamtoos Irrigation Board 
employees have been trained, and this Board has taken on the responsibility of controlling blackfly larvae in the river and in canals. The Bti is supplied by the National Department of Agriculture (Myburgh 1997; 1998a, b; 1999a).

\section{PRESENT AND FUTURE BLACKFLY RESEARCH}

Although an effective blackfly control programme is in place along the middle and lower Orange River, major outbreaks still occur (Palmer 1997; Myburgh 1999a). Some of these outbreaks can be attributed to human error (including unavailability of the helicopter and late ordering of larvicides), but a lack of information on several blackfly population dynamic factors makes planning of control actions difficult and inaccurate (Myburgh 2002). For example, in the current planning of control actions, fundamental fitness traits such as fecundity, dispersal, feeding, survival and longevity are poorly understood, although studies elsewhere have shown that these are all important considerations in the planning of control actions (Colbo \& Porter 1979; De Moor $1982 b)$. Due to the significance of these factors, the ARC-OVI, under contract to the Water Research Commission from 2000 to 2002, conducted a study to address some of the aspects believed to influence adult blackfly survival.

These studies showed that various physiological and ecological variables, such as body size, mass, lipid and glycogen levels, longevity, climatological factors (Myburgh 2002; 2003) and nectar availability (Myburgh, Bezuidenhout \& Nevill 2002) affect the survival of adult blackflies. The results of this study can be used, to some extent, to explain the typical seasonal variation found in the annoyance levels exhibited by adult blackflies along the lower Orange River and therefore, outbreaks can be predicted with more accuracy and blackfly control programmes can be adjusted accordingly. Current research focuses on the development of methods to protect livestock from the attacks of adult blackflies. These studies include the use of insecticides and shelters. Another aspect requiring attention is that blackflies along the Orange River may have developed resistance to temephos so that larval control programmes are no longer as effective when this larvicide is used. If this is the case, a strategy to overcome the resistance problem should be developed and/or a new larvicide tested and registered for use in South Africa. Moreover, the reason why periodic outbreaks during the summer months occur along the lower Orange River, below Onseepkans (Fig.1), is not known and this problem requires investigation.

In addition, the development of an effective control programme for the Vaal River blackfly problem needs to be developed as the control programme, developed for S. chutteri along the Orange River, is not entirely suitable for use along the Vaal River as the two river systems differ in certain respects. Some of the ways in which the Vaal River differs from the Orange River, are the following:

- Dams and other impoundments are more frequent along its course.

- It is not used for irrigation as extensively as the Orange River, and is then mostly via canals fed from weirs, e.g. Vaalharts scheme-therefore, the use of waterflow manipulation as a blackfly control option would be less disruptive to agriculture.

- It flows through a comparatively densely populated part of South Africa so there is a greater recreational demand on or near it.

- Because of its proximity to large cities the blackflies, which breed along its length, impact directly on associated human activities, e.g. conference venues or, indirectly, e.g. racing stableshuman activities with a high commercial value.

- Because the area through which it flows is less arid than that of the Lower Orange River, livestock production is more intensive and cattle are more important, especially dairy cattle-the immediate negative effect of blackfly attacks will be more apparent.

- Although S. chutteri is the dominant blackfly species, as it is along the Orange River, a second species, S. damnosum, may also occur in pest proportions. As its name implies $S$. damnosum also feeds on humans-therefore exacerbating the nuisance effect of blackflies.

- Simulium damnosum does not scatter eggs on the water surface, as does $S$. chutteri, but attaches them to surfaces below the water level. This suggests that methods to control each of the two blackfly species could differ.

- In recent years, the Lesotho Highlands Water Scheme has resulted in the regular supply of water, via the Liebenbergvlei River to the Vaal Dam, ensuring a more constant high flow of water in the Vaal River. This could favour the production of constantly high levels of blackflies 
and may create new breeding sites upstream of the Vaal Dam.

From the foregoing it is clear that for effective ongoing blackfly control to be achieved in the various river systems, continuous research to adjust and develop control programmes is essential.

\section{REFERENCES}

ANDERSON, J.R. \& VOSKUIL, G.H. 1963. A reduction in milk production caused by the feeding of blackflies (Diptera: Simuliidae) on dairy cattle in California, with notes on the feeding activity on other animals. Mosquito News, 23:126- 131.

BEGEMANN, G.J. 1980. Laboratory studies on the biology of Simulium nigritarse Coquillett and Simulium adersi Pomeroy (Diptera: Simuliidae). Onderstepoort Journal of Veterinary Research, 47:203-211.

BERNADO, M.J. \& CUPP, E.W. 1986. Rearing black flies (Diptera: Simuliidae) in the laboratory: mass scale in vitro membrane feeding and its application to collection of saliva and parasitological and repellant studies. Journal of Medical Entomology, 23:666-679.

BRIDGES, V.E., MCCLUSKEY, B.J., SALMAN, M.D., HURD, H.S. \& DICK, J. 1997. Review of the 1995 vesicular stomatitis outbreak in the western United States. Veterinary Medicine Today, 211:556-560.

BROWN, A.W.A. 1962. A new insecticide for the control of blackflies (Diptera: Simuliidae). Bulletin of the World Health Organization, 27:51-522.

CAR, M. 1983. The influence of water-level fluctuation on the drift of Simulium chutteri Lewis 1965 (Diptera: Nematocera) in the Orange River, South Africa. Onderstepoort Journal of Veterinary Research, 50:173-177.

CAR, M. 1984. Laboratory and field trials with two Bacillus thuringiensis var. israelensis products for Simulium (Diptera: Nematocera) control in a small polluted river in South Africa. Onderstepoort Journal of Veterinary Research, 51:141-144.

CAR, M. \& DE MOOR, F.C. 1984. The response of Vaal River drift and benthos to Simulium (Diptera: Nematocera) control using Bacillus thuringiensis var. israelensis $(\mathrm{H}-14)$. Onderstepoort Journal of Veterinary Research, 51:155-160.

CHUTTER, F.M. 1963. Hydrobiological studies on the Vaal River in the Vereeniging area. Part 1. Introduction, water chemistry and biological studies on the fauna of habitats other than muddy bottom sediments. Hydrobiologica, 21:165.

CHUTTER, F.M. 1968. On the ecology of the fauna of stones in the current in a South African river supporting a very large Simulium population. Journal of Applied Ecology, 5:531561.

COETZEE, A.N. 1982. The population structure and dynamics of Simulium in the Great Fish River, M.Sc. thesis. Rhodes University.

CROSSKEY, R.W. 1990. The natural history of blackflies. Chichester \& New York: John Wiley \& Sons.

CROSSKEY, R.W. 1993. Blackflies (Simuliidae), in Medical insects and arachnids, edited by P. Lane \& R.W. Crosskey. Chichester \& New York: John Wiley and Sons: 241-287.

COLBO, M.H.\& PORTER, G.N. 1979. Effects of food supply on the life history of Simuliidae (Diptera: Simuliidae). Canadian Journal of Zoology, 57:301-306.
DAVIES, D.M. \& PETERSON, B.V. 1956. Observations on the mating, feeding, ovarian development and oviposition of adult black flies (Simuliidae, Diptera). Canadian Journal of Zoology, 34:615-655.

DAVIES, D.M., PETERSON, B.V. \& WOOD, D.M. 1962. The black flies (Diptera: Simuliidae) of Ontario. Part I. Adult identification and distributions of six new species. Proceedings of the Entomological Society of Ontario, 92:70-154.

DAVIES, J.B. 1994. Sixty years of Ochocerciasis Vector Control: A chronological summary with comments on eradication, reinvasion, and insecticidal resistance. Annual Review of Entomology, 39:23-45.

DE MOOR, F.C. 1982a. Determination of the number of instars and size variation in the larvae and pupae of Simulium chutteri Lewis 1965 (Diptera: Simuliidae) and some bionomical implications. Canadian Journal of Zoology, 60:1374-1382.

DE MOOR, F.C. 1982b. A community of Simulium species in the Vaal River near Warrenton. Ph.D. thesis, University of the Witwatersrand.

DE MOOR, F.C. 1986. Blackfly problems in and along the Vaal River. Proceedings of a joint symposium convened by the Foundation for Research and Development and the Vaal River Catchment Association, Warrenton: 159-173.

DE MOOR, F.C. \& CAR, M. 1986. A field evaluation of Bacillus thuringiensis var. israelensis as a biological control agent for Simulium chutteri (Diptera: Nematocera) in the middle Orange River. Onderstepoort Journal of Veterinary Research, 53:43-50.

DE VILLIERS, P.C. 1987. Simulium dermatitis in man-clinical and biological features in South Africa. A case report. South African Medical Journal, 71:523-525.

EDMAN, J.D. \& SIMMONS, K.R. 1985. Rearing and colonization of black flies (Diptera: Simuliidae). Journal of Medical Entomology, 22:1-17.

EDWARDES, M., PALMER, R.W. 1994. The extent of the blackfly problem in South Africa. Report of the Onderstepoort Veterinary Institute, South Africa, for 1994.

GIBSON, G. \& TORR, S.J. 1999. Visual and olfactory responses of haematophagous Diptera to host stimuli. Medical and Veterinary Entomology, 13:2-23.

HADI, U. K. \& TAKAOKA, H. 1995. Effects of constant temperature on oviposition and immature development of Simulium bidentatum (Diptera: Simuliidae), a vector of bovine Onchocerca (Nematoda: Onchocercidae) in central Kyushu, Japan. Journal of Medical Entomology, 32:801-806.

HOCKING, B. 1953. The intrinsic range and speed of flight of insects. Transactions of the Royal Entomological Society of London, 99:475-496.

HOUGARD, J-M., YAMÉOGO, L., SÉKÉTÉLI, A., BOATIN, B. \& DADZIE, K.Y. 1997. Twenty-two years of blackfly control in the Onchocerciasis control programme in West Africa. Parasitology Today, 13:425-431.

HOWELL, C.J. \& HOLMES, G.W. 1969. The control of Simuliidae in the Vaalharts Irrigation Complex. Journal of the South African Veterinary Association, 40:59-67.

HOWELL, C.J., BEGEMANN, G.J., MUIR, R.W. \& LOUW, P. 1981. The control of Simuliidae (Diptera: Nematocera) in South African rivers by modification of the water flow volume. Onderstepoort Journal of Veterinary Research, 48: 47-49.

HUNTER, D.M. 1977. Sugar-feeding in some Queensland black flies. Journal of Medical Entomology, 14:229-232.

JORDAAN, L.C. \& VAN ARK, H. 1990. A survey of annoyance of livestock by Simulium chutteri Lewis along the Orange 
River, South Africa (Diptera: Simuliidae). Onderstepoort Journal of Veterinary Research, 57:189-195.

KETTLE, D.S. 1984. Medical and veterinary entomology. London: Croom Helm.

KOK, D.J., FOURIE, L.J. \& OBEREM, P.T. 1994. A method for the assessment of blackfly (Diptera: Simuliidae) attraction to and engorgement on sheep. Onderstepoort Journal of Veterinary Research, 61:7-11.

LACEY, L., ESCAFFRE, H., PHILIPPON, B., SÉKÉTÉLI, A. \& GUILLET, P. 1982. Large river treatment with Bacillus thuringiensis $(\mathrm{H}-14)$ for the control of Simulium damnosum s.l. in the Onchocerciasis Control Programme: preliminary trials with Sandoz 402 formulation. Tropenmedizin und Parasitologie, 33:97-101.

MARÉ, C.J. 1998. Vesicular stomatitis: ecology of the disease in the USA. What do we know? What do we believe? Conference Handbook Abstracts-Eighth International Conference on Equine Infectious Diseases, Dubai, United Arab Emirates, 23-26 March 1998: 67.

MASON, P.G. \& SHEMANSCHUK, J.A. 1990. Black flies. Agricultural Canada Publication 1499/E, Communications Branch\AgriculturelOttawalK1A0C7: 1-56.

MCINTOSH, B.M., JUPP, P.G., DOS SANTOS, I. \& BARNARD, B.J.H. 1980. Vector studies on Rift Valley Fever virus in South Africa. South African Medical Journal, 58:127-132.

MOLYNEUX, D.H. \& DAVIES, J.B. 1997. Onchocerciasis control: moving towards the millennium. Parasitology Today, 13: 418-425.

MYBURGH, E. 1997. Blackfly control in South Africa. Interim report on the control of blackfly in the Orange, Vaal, Gamtoos, Sundays and Fish Rivers for the contract year 1997/ 1998. Report No: OVI 97.13 for the National Department of Agriculture, Directorate of Agricultural Resource Conservation, Pretoria, December 1997.

MYBURGH, E. 1998a. Blackfly control in South Africa. Final report on the control of blackfly in the Orange, Vaal, Gamtoos, Sundays and Fish Rivers for the contract year 1997/ 1998. Report No: OVI 1998/001/UPT for the National Department of Agriculture, Directorate of Agricultural Resource Conservation, Pretoria, June 1998.

MYBURGH, E. 1998b. Blackfly control in South Africa. Interim report on the control of blackfly in the Orange, Vaal, Gamtoos, Sundays and Fish Rivers for the contract year 1998/ 1999. Report No: OVI 1998/006/UPT for the National Department of Agriculture, Directorate of Agricultural Resource Conservation, Pretoria, December 1998.

MYBURGH, E. 1999a. Control of blackflies in South Africa. Final report on the control of blackfly in the Orange, Vaal, Gamtoos, Sundays and Fish Rivers for the contract year 1998/ 1999. Report No: OVI 1999/006/UPT for the National Department of Agriculture, Directorate of Agricultural Resource Conservation, Pretoria, June 1999.

MYBURGH, E. 1999b. Control of the pest blackfly, Simulium chutteri, in the Orange River, South Africa. Journal of the South African Veterinary Association, 70:46.

MYBURGH, E. 2002. The influence of developmental temperature on the adult survival of Simulium chutteri (Diptera: Simuliidae). MSc Thesis, University of Pretoria.

MYBURGH, E. 2003. Factors that influence adult blackfly (Diptera: Simuliidae) survival along the lower Orange River, South Africa. Water Research Commission Report No. 1019/1/03, Pretoria, South Africa.

MYBURGH, E., BEZUIDENHOUT, H.B. \& NEVILL, E.M. 2002. The role of flowering plant species in the survival of black- flies (Diptera: Simuliidae) along the lower Orange River. Koedoe, 44:63-70.

NELSON, G.S. 1991. Human onchocerciasis: notes on the history, the parasite and life cycle. Annals of Tropical Medicine and Parasitology, 85:83-95.

NEVILL, E.M. 1988. The creation of permanent blackfly problems by the construction of dams, in Long-term data series relating to South Africa's renewable natural resources, edited by I.A.W. MacDonald \& R.J.M. Crawford. South African National Scientific Programmes Report No.157, CSIR, Pretoria, South Africa: 353-355.

O'KEEFFE, J.H. 1985. The blackfly problem in the Great Fish River. The Naturalist, 29:3-8.

PALMER, R.W. 1991. Ecological effects of impoundments in the Buffalo River, Eastern Cape, with particular reference to the distribution of blackflies (Diptera: Simuliidae), Ph.D. thesis, Rhodes University.

PALMER, R.W. 1993. Short-term impacts of formulations of Bacillus thuringiensis var. israelensis De Barjac and the organophosphate temephos, used in blackfly (Diptera: Simuliidae) control on rheophilic benthic macroinvertebrates in the middle Orange River, South Africa. South African Journal of Aquatic Science, 19:14-33.

PALMER, R.W. 1994. A rapid method of estimating the abundance of immature blackflies (Diptera: Simuliidae). Onderstepoort Journal of Veterinary Research, 61:117-126.

PALMER, R.W. 1995. Biological and chemical control of blackflies (Diptera: Simuliidae) in the Orange River. Water Research Commission Report No. 343/1/95, Pretoria, South Africa.

PALMER, R.W. \& PALMER, A.R. 1995. Impacts of repeated applications of Bacillus thuringiensis var. israelensis De Barjac and temephos used in blackfly (Diptera: Simuliidae) control, on macroinvertebrates in the middle Orange River, South Africa. South African Journal of Aquatic Science, 21: 35-55.

PALMER, R.W., EDWARDES, M. \& NEVILL, E.M. 1995a. Downstream carry of larvicides used in the control of pest black flies (Diptera: Simuliidae) in the Orange River, South Africa. Journal of Vector Ecology, 21:37-47.

PALMER, R.W., EDWARDES, M. \& NEVILL, E.M. 1995b.Timing of larvicide treatments for the control of pest blackflies (Diptera: Simuliidae) in a semi-arid environment in South Africa. Journal of Vector Ecology, 21:48-59.

PALMER, R.W., EDWARDES, M. \& NEVILL, E.M. 1996. Control of pest blackflies (Diptera: Simuliidae) along the Orange River, South Africa: 1990-1995. Onderstepoort Journal of Veterinary Research, 63:289-304.

PALMER, R.W. 1997. Principles of integrated control of blackflies (Diptera: Simuliidae) in South Africa. Water Research Commission Report No. 650/1/97, Pretoria, South Africa.

PALMER, R.W. 1998. An overview of black fly (Diptera: Simuliidae) control in the Orange River, South Africa. Israel Journal of Entomology, 32:99-110.

PALMER, R.W. \& DE MOOR, F.C. 1998. Annotated records of blackfly (Diptera: Simuliidae) distribution in southern Africa. African Entomology, 2:223-251.

PETERSON, B.V. 1959. Observations on mating, feeding and oviposition of some Utah species of black flies (Diptera: Simuliidae). The Canadian Entomologist, 91:147-155.

RODRIQUEZ-PEREZ, M.A., REYES-VILLANUEVA, F. \& RODRIQUEZ, M.H. 1995. Estimating the gonotrophic cycle and survivorship of Simulium ochraceum (Diptera: Simuliidae) 
during routine vector surveillance in Southern Mexico. Journal of the American Mosquito Control Association, 11:360362

SAMBA, E.M. 1995. Ten years of onchocerciasis control. Report of the World Health Organization, Geneva, for 1995, No. OCP/GVA/85.1B: 43-57.

SIMMONS, K.R., EDMAN, J.D. \& BENNETT, S.R. 1989. Collection of blood-engorged black flies (Diptera: Simuliidae) and identification of their source of blood. Journal of the American Mosquito Control Association, 5:541-546.

STEENKAMP, J.A. 1972. 'n Ondersoek na die wisselwerking tussen sommige ekologiese faktore en die bevolkings van Simulium damnosum Theobald en S. nigritarse Coquillett (Simuliidae: Diptera) in die Vaalrivier by Parys. D.Sc. thesis, Potchefstroom University.
SUTCLIFFE, J.F. 1986. Black fly host location: a review. Canadian Journal of Zoology, 64:1041-1053.

UNDEEN, A.H., TAKAOKA, H. \& HANSEN, K. 1981. A test of Bacillus thuringiensis var. israelensis de Barjac as a larvicide for Simulium ochraceum, the central American vector of onchocerciasis. Mosquito News, 41:37-40.

WELTON, J.S., BASS, J.A.B., LADLE, M. \& MERRITT, W.J. 1987. Distribution of oviposition sites and characteristics of the egg development in the "Blandford Fly" Simulium posticatum (Diptera: Simuliidae). Journal of Applied Ecology, 24: 865-879.

WILLIAMS, E.H. \& WILLIAMS, P.H. 1966. A note on an apparent similarity in distribution of onchocerciasis, femoral hernia and Kaposi's sarcoma in the West Nile District of Uganda. East African Medical Journal, 43:208-209. 